\title{
Assessment of Intramuscular Injection Practices of Health Workers in Urban Dispensaries
}

Sir,

Immunization is an important component of primary health care and a major strategy in disease prevention. All vaccine under childhood routine immunization programme except oral polio vaccine [OPV] is administered parentrally. A study was conducted to assess the intramuscular [IM] injection practices of health workers in urban dispensaries. Primary data was collected by a single investigator using observation checklist based on World Health Organization [WHO] guidelines for immunization [Hepatitis B] practices for children less than one year of age during the period October 2005 to March 2006 after obtaining permission from competent authority. All [32] government dispensaries operational in a randomly selected municipal zone of Delhi, India were covered in the present study. Atleast five intramuscular injections were observed in each health facility to comment on technique and practices and results presented according to health facility. ${ }^{1}$

The correct site [antero-lateral aspect of mid thigh] and correct angle $\left[90^{\circ}\right]$ for administration of intramuscular injection in infant's thigh was observed in 28 [87.5\%] and 20 [62.5\%] health facilities respectively (Table 1). However, when both the parameters were considered together, it was found to be correct only in 20 [62.5\%] health facilities. Further, in 4 [12.5\%] health facilities, not only the angle but the site of administration of intramuscular injection in infant was incorrect, i.e., upper $1 / 3^{\text {rd }}$ of thigh [3.12\%], lower $1 / 3^{\text {rd }}$ of thigh $[3.12 \%]$ and gluteal region $[6.25 \%]$.

In 20 health facilities where IM injection was administered at correct site and angle, it was observed that health worker in 14 [43.75\%] health facilities used her non-dominant hand to stretch infant's skin [WHO guidelines] and bunched up infants tissue mass in 6 [18.75\%] health facilities while inserting the needle. The overall observation was not found to be statistically

\begin{tabular}{|c|c|c|c|c|c|c|c|}
\hline \multirow[t]{2}{*}{$\mathrm{SN}$} & \multirow[t]{2}{*}{$\begin{array}{l}\text { Site and } \\
\text { of IM injection } \\
\text { in infant }\end{array}$} & \multicolumn{4}{|c|}{$\begin{array}{l}\text { Angle Activity of health worker at } \\
\text { the injection site using non } \\
\text {-dominant hand } \\
\text { StretchedBunched up } \\
\text { Skin \# tissue mass }\end{array}$} & \multicolumn{2}{|c|}{$\begin{array}{c}\text { Total } \\
\mathrm{N}=32(\%)\end{array}$} \\
\hline & & $\mathrm{N}$ & $\%$ & $\mathrm{~N}$ & $\%$ & $\mathrm{~N}$ & $\%$ \\
\hline 1 & $\begin{array}{l}\text { Correct site } \\
\text { [antero-lateral } \\
\text { aspect of mid } \\
\text { thigh] and } \\
\text { correct angle } \\
{\left[90^{\circ}\right] \#}\end{array}$ & 14 & 43.75 & 6 & 18.75 & 20 & 62.5 \\
\hline 2 & $\begin{array}{l}\text { Correct site but } \\
\text { incorrect angle }\end{array}$ & 6 & 18.75 & 2 & 6.25 & 8 & 25.0 \\
\hline 3 & $\begin{array}{l}\text { Incorrect site \& } \\
\text { angle }\end{array}$ & 4 & 12.5 & - & - & 4 & 12.5 \\
\hline
\end{tabular}

\# WHO guidelines $\chi^{2}=1.59, \mathrm{df}=2, \mathrm{p}>0.05$

significant $\left[c^{2}=1.59\right.$, d.f $\left.=2, p>0.05\right]$.

To conclude, only 14 [43.75\%] health facilities qualify WHO standards of intramuscular injection practices for infant on the parameters considered in present study. This is suggestive of need for reorientation training, motivation, constructive criticism and constant supervision of health personnel.

Sandeep Sachdeva and Utsuk Dutta ${ }^{1}$ National Consultant (BC), Ministry of Health and Family Welfare, Nirman Bhawan, New Delhi-110108, India ${ }^{1}$ Reader and Acting Head, Department of Education and Training, NIHFW, New Delhi-110067, India E-mail: drsandeepsachdeva@gmail.com

[DOI-10.1007/s12098-009-0113-2]

\section{REFERENCE}

1. Immunization in Practice: A practical guide for health staff. 2004 Update. World Health Organization, Geneva. WHO/ IVB $/ 04 / 06$. 